\title{
ROC-1, P21 and CAIX as markers of tumor aggressiveness in bladder carcinoma in Egyptian patients
}

Dalia Rifaat Al-Sharaky ${ }^{*}$, Mona Abd El-Halim Kandil ${ }^{1}$, Hayam Abdel Samie Aiad', Enas Megahed El-hosary², Hagar Abdelmagied Alagizy ${ }^{3}$, Mahmoud Abdel-Sattar Elshenawy ${ }^{3}$ and Hala Said El-Rebey ${ }^{1}$

\begin{abstract}
Background: Bladder cancer (BC) is one of the most common malignancies in Egypt, representing about 8.7\% of cancers in both sexes with more predominance in males, making identification of valuable predictive and prognostic markers, mandatory. Cullin-RING ligases (CRL) play an important role in the ubiquitination of cell cycle-related proteins or other proteins (e.g., DNA replication protein, signal transduction protein). Regulator of Cullins-1 (ROC-1) is a key subunit of CRL. P21 belongs to the family of cyclin dependent kinase inhibitors (CKIs) which regulates cell cycle by inactivating Cyclin- Dependent Kinases key regulators of the cell cycle. CAIX a highly active member of the family of carbonic anhydrases has gained much interest as a hypoxic marker. Hypoxia is a consequence of the rapid growth of many tumors, including bladder cancer, and is an important regulator of gene expression and resistance to chemotherapy and radiotherapy. Therefore the purpose of this study is to evaluate the role of ROC-1, CAIX and P21 and its relationship with the clinico-pathological features of bladder cancer in Egyptian patients.
\end{abstract}

Methods: Using the standard immunohistochemical technique, ROC-1, CAIX and P21 expression in 80 primary bladder carcinomas and 15 normal bladder specimens as control group were assessed. The bladder carcinoma cases included 50 cases with muscle invasive bladder cancer and 30 cases with non-muscle invasive bladder cancer.

Results: Over expression of ROC-1, CAIX and P21 in BC were significantly associated with muscularis propria invasion and high grade BC. ROC-1, CAIX and P21, showed significant inverse relationship in primary BC cases. CAIX expression was significantly higher in $\mathrm{BC}$ compared with controls. Regarding the survival analysis, expression of ROC-1, CAIX and P21 didn't affect the survival of BC patients.

Conclusions: High expression of ROC-1, CAIX and P21 could be promising potential biomarkers for identifying patients with poor prognostic factors in bladder cancer serving as potential targets for cancer therapy.

Keywords: ROC-1, CAIX, P21, BC, Immunohistochemistry, Prognosis

\footnotetext{
*Correspondence: daliah_alsharaky@yahoo.com

'Department of Pathology, Faculty of Medicine, Menoufia University, Shebin El-Kom, Menoufia Governorate 35211, Egypt

Full list of author information is available at the end of the article
}

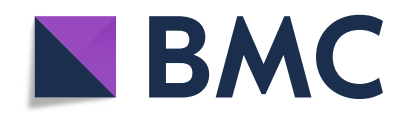

(C) The Author(s). 2020 Open Access This article is licensed under a Creative Commons Attribution 4.0 International License, which permits use, sharing, adaptation, distribution and reproduction in any medium or format, as long as you give appropriate credit to the original author(s) and the source, provide a link to the Creative Commons licence, and indicate if changes were made. The images or other third party material in this article are included in the article's Creative Commons licence, unless indicated otherwise in a credit line to the material. If material is not included in the article's Creative Commons licence and your intended use is not permitted by statutory regulation or exceeds the permitted use, you will need to obtain permission directly from the copyright holder. To view a copy of this licence, visit http://creativecommons.org/licenses/by/4.0/. The Creative Commons Public Domain Dedication waiver (http://creativecommons.org/publicdomain/zero/1.0/) applies to the data made available in this article, unless otherwise stated in a credit line to the data. 


\section{Background}

In Egypt bladder cancer is the third common malignancy accounting for $8.7 \%$ of all cancers according to National Cancer Registry with expected new cases about 10,709 by $2020,12,762$ by 2025 and 28,337 by $2050[1,2]$. Interest in understanding the molecular profiling of bladder carcinoma, to understand the biology of these tumors and to develop novel therapies has developed.

Cullin-RING ligases (CRL) are the largest family of E3 ubiquitin ligases [3]. Regulator of Cullins-1 (ROC1 ) is a key subunit of CRL, also known as RING box protein-1 (RBX1) [4]. ROC-1 knockdown arrest the cells at $\mathrm{G} 2 / \mathrm{M}$ phase of cell cycle by up regulating cyclin B1, P21 and P27 which is a useful strategy in treating various human cancers [5]. Some studies proved that ROC-1 protein is overexpressed in nonmuscle invasive bladder cancer, suggesting its potential role in bladder cancer development and progression [6].

P21 belongs to the CIP/KIP (CDK Interacting Protein/ Kinase Inhibitor Protein) family of cyclin dependent kinase inhibitors (CKIs) that includes also p27 and p57. These proteins were identified for their ability to regulate cell cycle by inactivating Cyclin- Dependent Kinases (CDKs), key regulators of the cell cycle. P21 has a different prognostic role in several cancers and according to the cellular context in which it is expressed; it can have a dual role being a target of specific therapies, or a marker of poor prognosis [7].

CAIX is a highly active member of the family of carbonic anhydrases with an ability to catalyze efficiently the reversible hydration of carbon dioxide to carbonic acid. CAIX can be designated as cancerrelated protein which is almost exclusively associated with tumors, and is overexpressed in some tumors. Therefore, inhibition of CAIX is considered as a promising therapeutic target for the treatment of solid tumors where hypoxic environment has developed [8].

The aim of this study is to evaluate the immunohistochemical expression of ROC-1, CAIX and p21 in correlation with the clinicopathological and prognostic parameters.

\section{Methods}

This retrospective study included 80 primary bladder carcinoma and 15 normal bladder specimens (control group). The bladder carcinoma cases included 50 cases with MIBC and 30 cases of NMIBC. The cases were retrieved from the archives of Pathology Department, Faculty of Medicine, Menoufia University spanning the period between January 2014 and December 2016.

\section{Clinical data of the studied groups}

Clinical data were obtained from patients' medical records and documented in (Table 1).

\section{Histopathological assessment}

The hematoxylin and eosin (H\&E) stained sections were evaluated for the followings; Histological type according to WHO classification, 2016. Tumor grading was done according to WHO/ISUP grading criteria [9]. The mitosis and apoptosis were counted semi quantitatively in ten randomly selected high power fields [10]. Depth of invasion and staging of the tumor were defined according to TNM American Joint Committee on CancerUnion International Center Cancer staging system (AJCC-UICC) which classifies the tumor histologically as NMIBC (stage pTa and pT1) or MIBC (stage pT2, pT3 and pT4) [9].

\section{Immunohistochemistry}

The method used for immunostaining was streptavidinbiotin amplified system. Sections cut from the paraffinembedded blocks were stained with Anti-ROC-1 (cat\# SC-5200, Santa Cruz) purified mouse monoclonal antibody received as $0.1 \mathrm{ml}$ conc. and diluted by phosphate buffer saline (PBS) in a dilution of 1:100. Anti-P21 (cat\# YPA1643, Snuff) rabbit polyclonal antibody received as $0.1 \mathrm{ml}$ conc. and diluted by PBS in a dilution of 1:400 and Anti-CAIX (cat \# YPA1250, Snuff) rabbit polyclonal antibody received as $0.1 \mathrm{ml}$ conc. and diluted by PBS in a dilution of 1:100.

Tissue sections prepared from seminiferous tubules of testis, papillary thyroid carcinoma and normal gastric mucosa were used as positive control for ROC-1, P21 and CAIX respectively. Negative control slides were also included in each run by omitting the primary antibody.

Positive cases for both ROC-1and P21were assigned as long as cytoplasmic or nucleo-cytoplasmic expression in $\geq 10 \%$ of cells was identified [11, 12]. Cytoplasmic or nucleo-cytoplasmic staining of CAIX in $>1 \%$ of cells was defined as positive immunoreaction [13].

\section{Statistical analysis}

The statistical analysis was conducted using SPSS "statistical package for the social science" program for windows, version 22.0 (SPSS INC., Chicago, Illinosis, USA). Contingency tables were analyzed with descriptive statistics [Arithmetic mean $(\overline{\mathrm{x}})$,Standard deviation (SD), Percentage (\%), Median and Range] and analytic statistics [Chi- square test $\left(x^{2}\right.$ - test), Mann-Whitney $Z$ test (Z test), Kruskal-Wallis test (K test), Fisher's exact (FE)]. Overall survival (OS) was analyzed using the KaplanMeier method, and differences were examined using logrank tests. Cox's proportional hazard regression test was used to estimate univariate and multivariate hazard 
Table 1 Clinicopathological data of the studied bladder carcinoma cases

\begin{tabular}{|c|c|c|}
\hline Variables & Category & No. (\%) \\
\hline \multirow[t]{2}{*}{ Age } & Mean \pm SD & $\begin{array}{l}62 \pm \\
8.76\end{array}$ \\
\hline & Range & $45-96$ \\
\hline \multirow[t]{3}{*}{ Sex } & Male & $\begin{array}{l}72 \\
(90 \%)\end{array}$ \\
\hline & Female & $8(10 \%)$ \\
\hline & $M: F$ & $8: 1$ \\
\hline \multirow[t]{2}{*}{ Size } & Mean $\pm S D$ & $4.64 \pm 2$ \\
\hline & Range & $1-10$ \\
\hline \multirow{2}{*}{$\begin{array}{l}\text { Muscularis propria } \\
\text { invasion } \\
\text { Urothelial carcinoma }\end{array}$} & Non-invasive & $\begin{array}{l}30 \\
(37.50 \%)\end{array}$ \\
\hline & Invasive & $\begin{array}{l}50 \\
(62.50 \%)\end{array}$ \\
\hline \multirow[t]{4}{*}{ Histologic Type } & Infiltrating UC & $\begin{array}{l}58 \\
(72.5 \%)\end{array}$ \\
\hline & $\begin{array}{l}\text { UC with divergent differentiation } \\
\text { (squamous or glandular) }\end{array}$ & $\begin{array}{l}14 \\
(17.5 \%)\end{array}$ \\
\hline & Squamous cell carcinoma & $\begin{array}{l}5 \\
(6.25 \%)\end{array}$ \\
\hline & Small cell neuroendocrine & $\begin{array}{l}3 \\
(3.75 \%)\end{array}$ \\
\hline \multirow[t]{2}{*}{$\begin{array}{l}\text { Gradingofurothelial } \\
\text { carcinoma }\end{array}$} & Low & $\begin{array}{l}14 \\
(18.7 \%)\end{array}$ \\
\hline & High & $\begin{array}{l}61 \\
(81.3 \%)\end{array}$ \\
\hline \multirow{2}{*}{$\begin{array}{l}\text { Grading of squamous } \\
\text { cell carcinoma }\end{array}$} & Moderately differentiated & $4(80 \%)$ \\
\hline & Poorly differentiated & $1(20 \%)$ \\
\hline \multirow[t]{2}{*}{ Bilharziasis } & Present & $\begin{array}{l}26 \\
(32.50 \%)\end{array}$ \\
\hline & Absent & $\begin{array}{l}54 \\
(67.5 \%)\end{array}$ \\
\hline \multirow[t]{2}{*}{ Necrosis } & Present & $\begin{array}{l}20 \\
(25 \%)\end{array}$ \\
\hline & Absent & $\begin{array}{l}60 \\
(75 \%)\end{array}$ \\
\hline \multirow[t]{2}{*}{$\begin{array}{l}\text { Lymph-vascular } \\
\text { invasion }\end{array}$} & Present & $\begin{array}{l}14 \\
(17.50 \%)\end{array}$ \\
\hline & Absent & $\begin{array}{l}66 \\
(82.50 \%)\end{array}$ \\
\hline \multirow[t]{2}{*}{ Perineural invasion } & Present & $\begin{array}{l}8 \\
(10.00 \%)\end{array}$ \\
\hline & Absent & $\begin{array}{l}72 \\
(90.00 \%)\end{array}$ \\
\hline \multirow[t]{2}{*}{ Stromal reaction } & Desmoplastic & $\begin{array}{l}60 \\
(75.00 \%)\end{array}$ \\
\hline & Inflammatory & $\begin{array}{l}20 \\
(25.00 \%)\end{array}$ \\
\hline \multirow[t]{2}{*}{$\begin{array}{l}\text { Lymph node stage } \\
\text { (TNM) }\end{array}$} & No & $\begin{array}{l}25 \\
(50.00 \%)\end{array}$ \\
\hline & N1 & $\begin{array}{l}9 \\
(18.00 \%)\end{array}$ \\
\hline
\end{tabular}

Table 1 Clinicopathological data of the studied bladder carcinoma cases (Continued)

\begin{tabular}{lll}
\hline Variables & Category & No. (\%) \\
\hline & N2 & 16 \\
Mitotic index & low index & $(32.00 \%)$ \\
& & 50 \\
& High index & $(62.25 \%)$ \\
Apoptotic index & low index & 30 \\
& & $(37.50 \%)$ \\
& High index & 44 \\
& & $(55.00 \%)$ \\
& & 36 \\
\end{tabular}

SD Standard deviation, No number, UC Urothelial carcinoma

ratios for prognosis. $P$ values of $\leq 0.05$ were considered statistically significant [14].

\section{Results}

Clinicopathologic characteristics:

Clinicopathologic characteristics of primary bladder carcinoma cases are summarized in (Table 1).

Immunohistochemical profile of ROC-1, CAIX and p21 in the studied bladder cancer cases were summarized in (Table 2)

Comparison between malignant and control groups regarding ROC-1, P21 and CAIX expression (Table 3)

CAIX was significantly expressed in bladder carcinoma than in normal urothelium $(P=0.01)$, however ROC-1 and P21 revealed no significant difference between the normal urothelium and bladder carcinoma.

\section{Relationship between ROC-1, P21 and CAIX expression} and clinicopathological factors in primary bladder carcinoma cases

ROC-1

Small sized tumors $(P=0.03)$, invasive urothelial carcinoma $(P=0.04)$, high grade UC $(P=0.04)$, cases with absent necrosis $(p=0.04)$, infiltrating $\mathrm{UC}$ in comparison to other types (SCC and small cell neuroendocrine carcinoma) $(P=0.05)$ and also cases that displayed desmoplastic stroma $(P=0.03)$ significantly overexpressed ROC-1. As for the subcellular localization, nucleo-cytoplasmic expression of ROC-1 was in favor of old aged patients $(P=0.000)$ and small sized tumors $(P=0.01)$ together with muscle invasive UC $(P=0.000)$, presence of bilharzial ova $(P=0.008)$ and high mitotic index $(P=0.004)$ (Fig. 1).

\section{P21}

P21overexpression was significantly in favor of muscle invasive $(P=0.02)$, high grade UC $(P=0.02)$ and high apoptotic index $(P=0.05)$. Cytoplasmic expression of 
Table 2 Immunohistochemical profile of the studied ROC1,CAIX and p21 in the studied bladder carcinoma cases

\begin{tabular}{|c|c|}
\hline Variables & $\begin{array}{l}\text { Malignant cases }(\mathrm{No}=80) \\
\text { No }(\%)\end{array}$ \\
\hline \multicolumn{2}{|l|}{ ROC1 expression } \\
\hline Positive & $72(90 \%)$ \\
\hline \multirow[t]{2}{*}{ Negative } & $8(10 \%)$ \\
\hline & $\mathrm{No}=72$ \\
\hline \multicolumn{2}{|l|}{ RCO1 subcellular localization } \\
\hline Cytoplamic & $24(33.3 \%)$ \\
\hline Nucleo-cytoplasmic & $48(66.7 \%)$ \\
\hline \multicolumn{2}{|l|}{ ROC-1 intensity } \\
\hline Predominant strong & $18(25.0 \%)$ \\
\hline Predominant moderate & $30(41.7 \%)$ \\
\hline Predominant mild & $24(33.3 \%)$ \\
\hline \multicolumn{2}{|l|}{ ROC1 H.score } \\
\hline Low expression & $37(51.4 \%)$ \\
\hline High expression & $35(48.6 \%)$ \\
\hline \multicolumn{2}{|l|}{ CAX expression } \\
\hline Positive & 49 (92.5\%) \\
\hline \multirow[t]{2}{*}{ Negative } & $31(73.8 \%)$ \\
\hline & No $=49$ \\
\hline \multicolumn{2}{|c|}{ CAX subcellular localization } \\
\hline Cytoplamic & $44(89.7 \%)$ \\
\hline Nucleo-cytoplasmic & $5(10.2 \%)$ \\
\hline
\end{tabular}

CAIX intensity

Predominant strong

Predominant moderate

Predominant mild

CAX H-score

Low expression

$31(63.3 \%)$

High expression

$18(36.7 \%)$

P21 expression

Positive

Negative

$67(83.75 \%)$

$13(16.25 \%)$

No $=67$

P21 subcellular localization

Cytoplamic

$55(82.1 \%)$

Nucleo-cytoplasmic

P21 intensity

Predominant strong

Predominant moderate

Predominant mild
Table 2 Immunohistochemical profile of the studied ROC1, CAIX and p21 in the studied bladder carcinoma cases (Continued)

\begin{tabular}{lc}
\hline Variables & $\begin{array}{l}\text { Malignant cases (No }=80) \\
\text { No }(\%)\end{array}$ \\
\hline P21 H-score & \\
Low expression & $34(50.7 \%)$ \\
High expression & $49(92.5 \%)$ \\
\hline No number &
\end{tabular}

No number

P21 was significantly in favor of muscle invasive cases $(P=0.001)$, presence of necrosis $(P=0.028)$, advanced T stage $(P=0.004)$, high apoptotic index $(P=0.001)$ and high mitotic index $(P=0.002)$ (Fig. 2).

\section{CAIX}

High grade urothelial carcinoma displayed significant CAIX overexpression in comparison with low grade tumors $(P=0.01)$.

Furthermore, a significant association between positive CAIX expression and female gender $(P=0.02)$, presence of bilharziasis $(P=0.046)$ and desmoplastic stroma $(P=0.024)$ was present (Fig. 3).

In our study, there were 20 cases of the urothelial carcinoma that displayed necrosis; CAIX was evaluated around necrosis (perinecrotic) and away from necrotic area. In the perinecrotic area, 12 cases out of 20 displayed membranous expression of CAIX, while in areas away from necrosis 4 cases only out of 20 were positive for CAIX.

All the cases that were positive for CAIX expression in the perinecrotic area were negative in areas away from necrosis $(P=0.014)$. However, half of the cases that showed negative expression in the perinecrotic area were also negative in areas away from necrosis (Table 4).

\section{Correlation between ROC-1 H-score and both CAIX and P21 H-scores in malignant cases (Table 5)}

There was a significant inverse relationship between ROC-1 $\mathrm{H}$-score and both CAIX and P21 $\mathrm{H}$-scores $(P=0.02$ and 0.01 respectively).

\section{Survival analysis}

After exclusion of low grade, small cell and urothelial carcinoma with squamous differentiation, none of the studied ROC-1, CAIX or P21 expressions showed significant impact on overall survival (Table 6).

\section{Discussion}

In the present study, ROC-1 showed expression in 90 and $93 \%$ of the bladder cancer cases and normal urothelial tissues respectively. Increased expression in the $\mathrm{BC}$ can be explained by its role in mediating degradation of 
Table 3 Comparison between ROC1, P21 and CAIX expression in control group and bladder carcinoma cases

\begin{tabular}{|c|c|c|c|c|c|}
\hline Variables & Category & control group $(\boldsymbol{n}=15)$ & Malignant group $(\boldsymbol{n}=80)$ & Test of significance & $p_{\text {p_value }}$ \\
\hline \multirow{2}{*}{$\begin{array}{l}\text { ROC1 } \\
\text { expression }\end{array}$} & Negative & $1(6.66 \%)$ & $8(10 \%)$ & \multirow[t]{2}{*}{$F E=0.16$} & \multirow[t]{2}{*}{1} \\
\hline & Positive & $14(93.33 \%)$ & 72 (90\%) & & \\
\hline \multirow[t]{2}{*}{ ROC1 Sub cellular localization } & Cytoplasmic & $8(57.14 \%)$ & $24(33.3 \%)$ & \multirow[t]{2}{*}{$x^{2}=2.84$} & \multirow[t]{2}{*}{0.09} \\
\hline & Nucleocytoplasmic & $6(42.86 \%)$ & $48(66.7 \%)$ & & \\
\hline \multirow{2}{*}{$\begin{array}{l}\text { ROC1 } \\
\text { H-score }\end{array}$} & Low expression & $8(57.1 \%)$ & $37(51.4 \%)$ & \multirow[t]{2}{*}{$x^{2}=0.16$} & \multirow[t]{2}{*}{0.69} \\
\hline & High expression & $6(42.9 \%)$ & $35(48.6 \%)$ & & \\
\hline \multirow[t]{2}{*}{ P21 expression } & Negative & $5(33.3 \%)$ & $13(16.25 \%)$ & \multirow[t]{2}{*}{$\mathrm{FE}=2.4$} & \multirow[t]{2}{*}{0.1} \\
\hline & Positive & $10(66.7 \%)$ & 67 (83.75\%) & & \\
\hline \multirow[t]{2}{*}{ P21 Sub cellular localization } & Cystoplasmic & $8(80 \%)$ & $55(82.1 \%)$ & \multirow[t]{2}{*}{$F E=0.03$} & \multirow[t]{2}{*}{1} \\
\hline & Nucleocytoplasmic & $2(20 \%)$ & $12(17.9 \%)$ & & \\
\hline \multirow[t]{2}{*}{ P21 H-score } & Low expression & $5(50 \%)$ & $34(50.7 \%)$ & \multirow[t]{2}{*}{$\mathrm{FE}=0.002$} & \multirow[t]{2}{*}{1} \\
\hline & High expression & $5(50 \%)$ & $33(49.3 \%)$ & & \\
\hline \multirow[t]{2}{*}{ CAIX expression } & Negative & $11(26.2 \%)$ & $31(73.8 \%)$ & \multirow[t]{2}{*}{$x 2=6.13$} & \multirow[t]{2}{*}{$0.01^{*}$} \\
\hline & Positive & $4(7.5 \%)$ & $49(92.5 \%)$ & & \\
\hline \multirow[t]{2}{*}{ CAIX Sub cellular localization } & Cystoplasmic & $4(8.3 \%)$ & $44(91.7 \%)$ & \multirow[t]{2}{*}{$\mathrm{FE}=0.45$} & \multirow[t]{2}{*}{1} \\
\hline & Nucleocytoplasmic & $0(0 \%)$ & $5(100 \%)$ & & \\
\hline \multirow[t]{2}{*}{ CAIX H-score } & Low expression & $1(3.1 \%)$ & 31 (96.9\%) & \multirow[t]{2}{*}{$\mathrm{FE}=0.22$} & \multirow[t]{2}{*}{1} \\
\hline & High expression & $3(14.3 \%)$ & $18(85.7 \%)$ & & \\
\hline
\end{tabular}

No number, ${ }^{*}$ significant, FE fisher's exact test

tumor suppressors and DNA replication licensing proteins which would accelerate cell growth. Furthermore, correlation between ROC-1 and Ki67 as reported by Migita and colleagues [15] might help in proliferation of cancer cells. Several studies support the increased expression of ROC-1 in BC in our study $[6,15,16]$.
Overexpression of ROC-1 in the malignant group was significantly associated with poor prognostic factors in the current study as invasion into muscularis propria, and high grade UC. Increase of ROC-1 expression from early to advanced $\mathrm{BC}$, supports its poor prognostic impact and implies a potential role in BC progression.

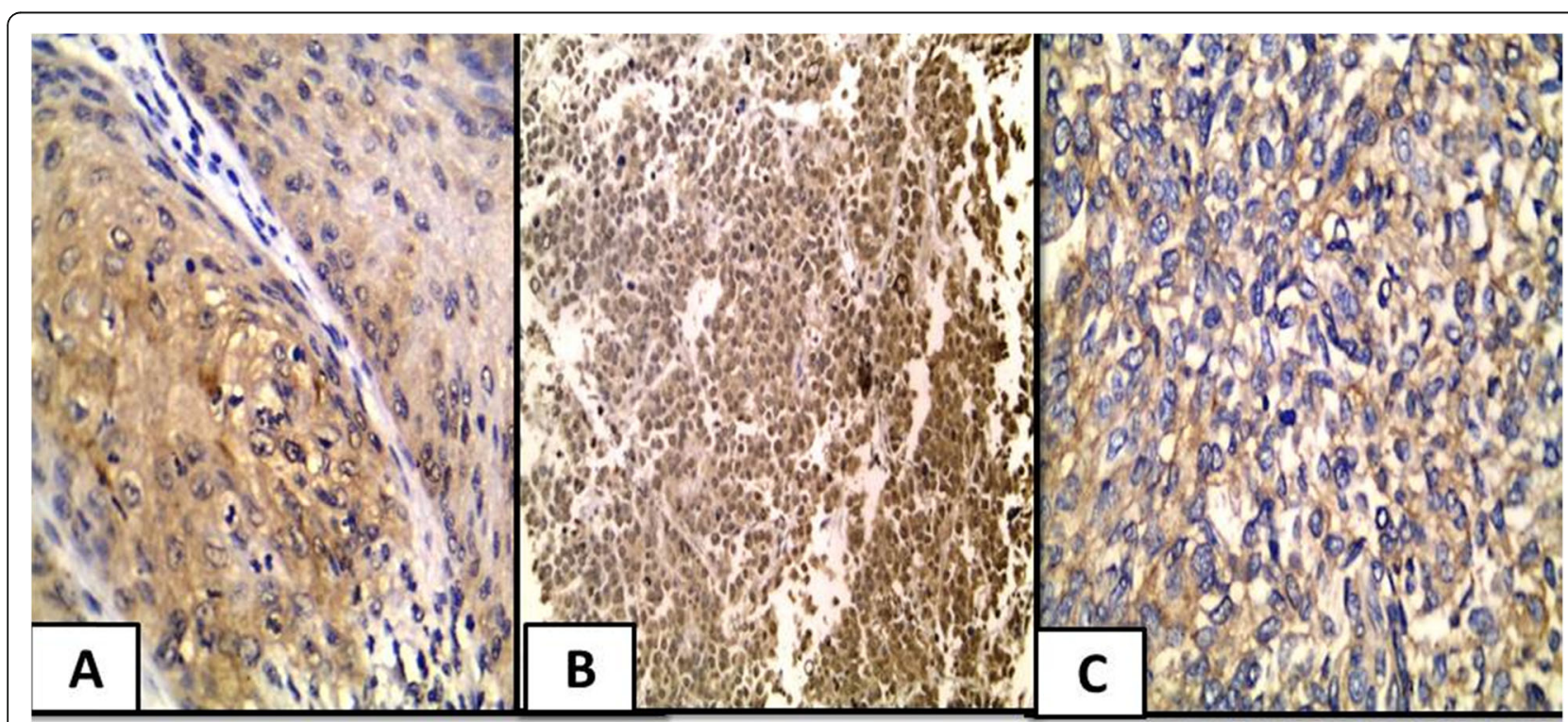

Fig. 1 ROC-1 expression in studied cases. a A case of moderately differentiated squamous cell carcinoma showed positive moderate cytoplasmic expression of ROC-1 (IHC $\times 200 / 400)$. b A case of small cell neuroendocrine carcinoma showed positive strong nucleocytoplasmic expression of ROC-1 (IHC $\times 200)$ c A case of invasive urothelial carcinoma, high grade showed positive mild cytoplasmic expression of ROC-1 (IHC $\times 400)$ 


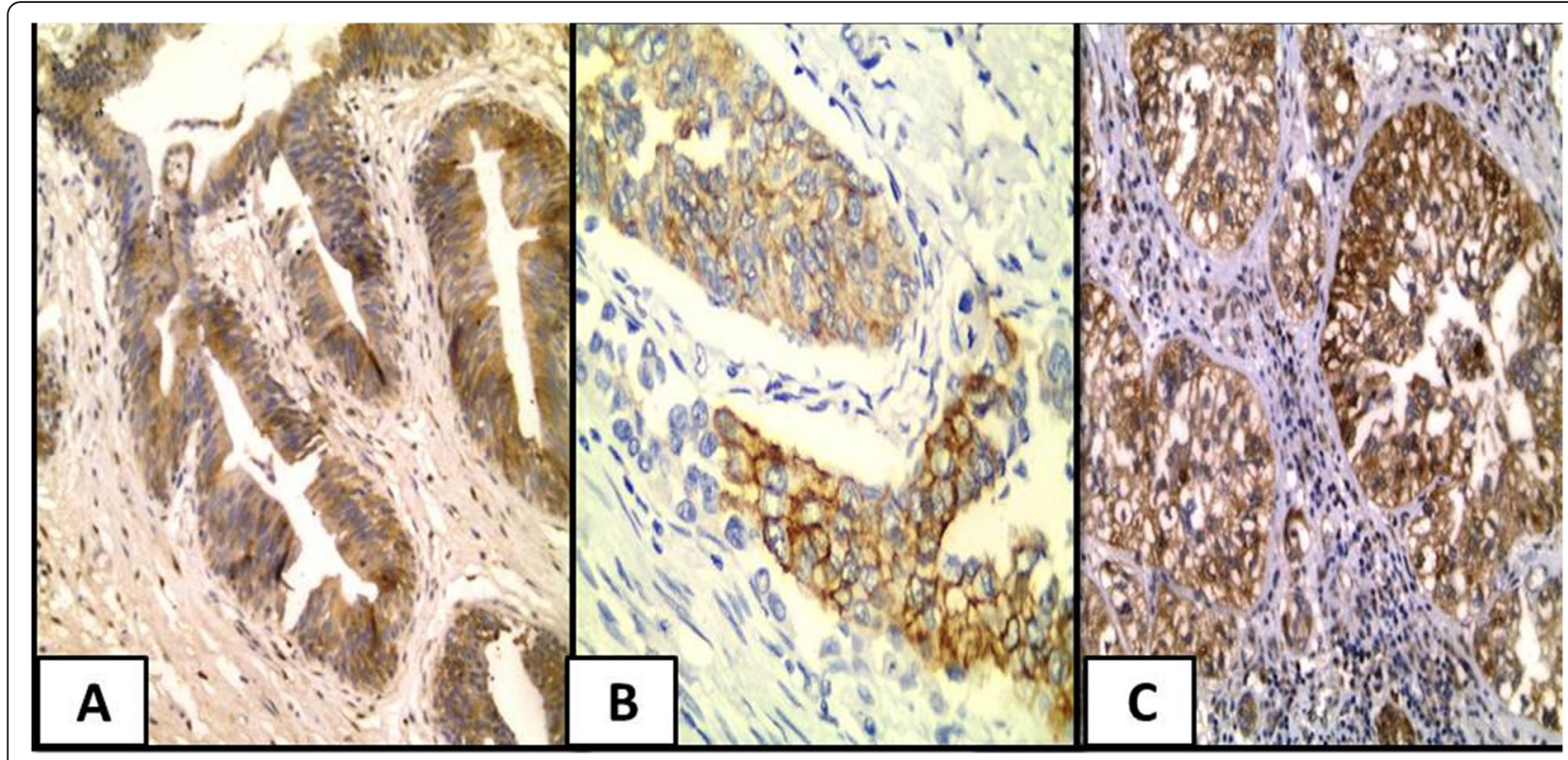

Fig. 2 P21 expression in studied cases. a A case of normal urothelium showed positive P21 expression in urothelial cells (IHC $\times 400)$. b A case of invasive urothelial carcinoma, high grade showed positive mild cytoplasmic expression of P21 (IHC $\times 400)$. c A case of invasive urothelial carcinoma, high grade showed positive strong cytoplasmic expression of P21 (IHC ×400)

ROC-1 overexpression significant association with desmoplastic stroma was consistent with others supporting the role of ROC-1 as an EMT [17-19]. Knockdown of ROC-1 transactivates the RhoA and Rac1 signaling pathways and inhibits mTOR activity, which has a pivotal role in regulation of various cellular processes including EMT, thus causing suppression of EMT in MIBC [20-24].
The relation between ROC-1 and necrosis in $\mathrm{BC}$ in the present study is an inverse relation. This can be explained by ROC-1 mediated down regulation of hypoxic marker CAIX, for ROC-1 ubiquities VHL which degraded hypoxic marker CAIX [25-27]. So there is an inverse relation between hypoxic marker CAIX released in the hypoxic conditions as necrosis and with ROC-1.

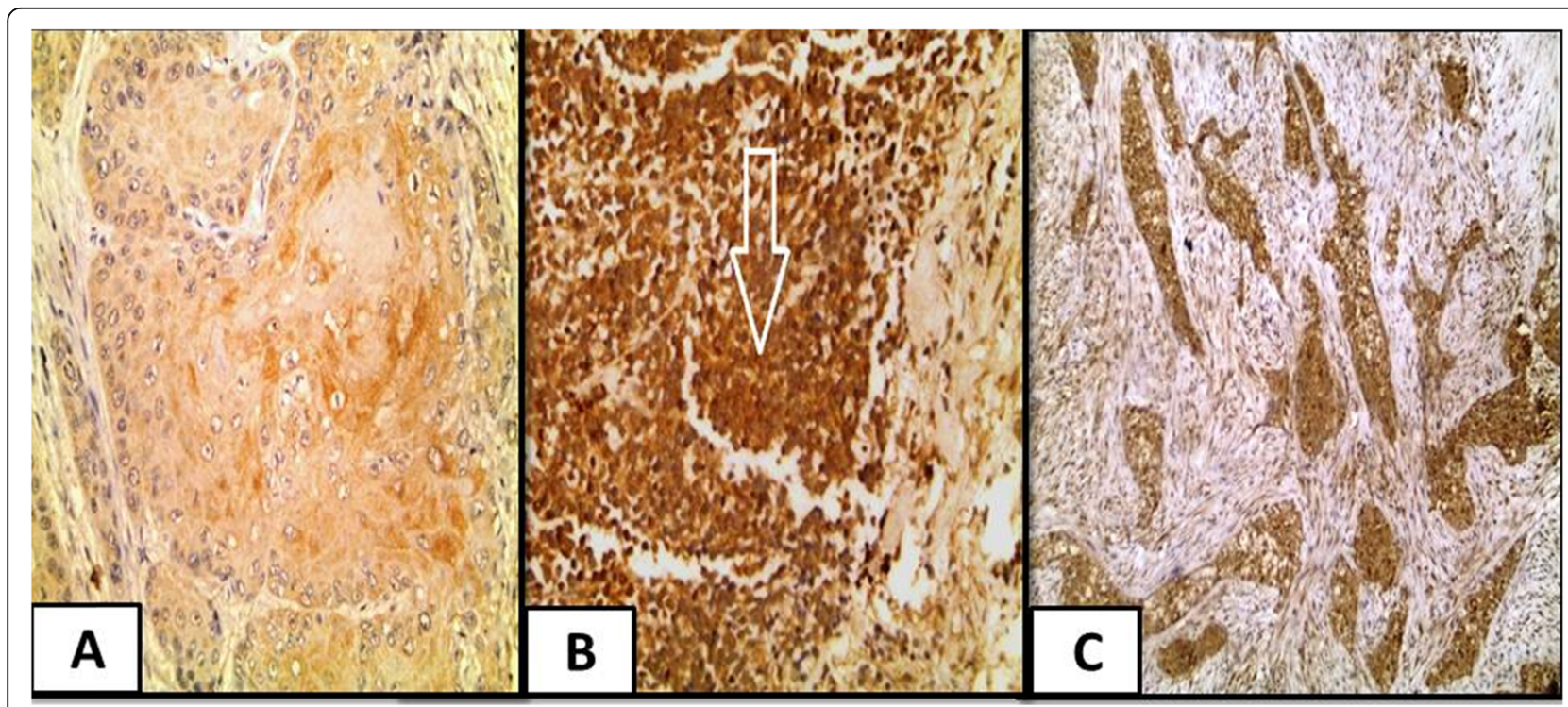

Fig. 3 CAIX expression in studied cases. a A case of moderately differentiated squamous cell carcinoma showed positive moderate cytoplasmic expression of CAIX (IHC $\times 400)$. b A case of small cell neuroendocrine carcinoma showed positive strong cytoplasmic expression of CAIX (IHC $\times$ 400).c A case of invasive urothelial carcinoma, high grade with positive strong cytoplasmic expression of CAIX and positive desmoplastic stromal reaction $(\mathrm{IHC} \times$ 200) 
Table 4 Relationship between CAIX expression in malignant cells perinecrotic and away from necrosis

\begin{tabular}{|c|c|c|c|c|}
\hline \multirow[t]{2}{*}{ Variables } & \multicolumn{2}{|c|}{ Perinecrotic $(\mathrm{No}=20)$} & \multirow{2}{*}{$\begin{array}{l}\text { Test of } \\
\text { significance }\end{array}$} & \multirow{2}{*}{$\begin{array}{l}P_{-} \\
\text {Value }\end{array}$} \\
\hline & Negative $(\mathrm{No}=8)$ & Positive $(\mathrm{No}=12)$ & & \\
\hline Away from necrosis $(\mathrm{No}=20)$ & & & $\mathrm{FE}=7.5$ & $0.014^{*}$ \\
\hline Negative $(\mathrm{no}=16)$ & $4(50 \%)$ & $12(100 \%)$ & & \\
\hline Positive $(n o=4)$ & $4(50 \%)$ & $0(0 \%)$ & & \\
\hline
\end{tabular}

NB: The percentage is calculated by column

* significant, No number, FE fisher's exact test

As for the association between nucleo-cytoplasmic expression of ROC-1 and aggressive pathologic features of $\mathrm{BC}$ (as muscle invasion, high mitosis, presence of bilharzial infection and old age), it was supported by a study done by Wang and colleagues [6] reporting association of nuclear expression with aggressive BC. ROC-1 mediated ubiquitination and degradation of nuclear proteins may contribute to bladder cancer development and progression is speculated. When ROC-1 is overexpressed specially in the nucleus skp2 of SCF complex recognizes and promotes degradation of $\mathrm{p} 21$ or $\mathrm{p} 27$ proteins and in turn causes cell unregulated proliferation, a primary alteration in cancer cells [6].

As for the P21, it displayed over expression in 83.8\% of bladder cancer cases which agrees with several studies [28-30]. P21 overexpression reflected poor prognostic impact in $\mathrm{BC}$ which is proved by its role in tumorgenesis and cancer progression [29-33]. It has been proposed that progressive cancers accumulate p21 resulting in proliferation of the tumor cells. Also, in BC p21 can act in p53 dependent manner which is one of the predominant components of $\mathrm{BC}$ development or by other p53independent pathways, including transforming growth factor beta (TGF- $\beta$ ) signaling [30].

High apoptotic association with P21over expression, is in concordance with Wang et al. [34], for P21 is a powerful CDK inhibitor and its protein has a cyclin binding motif and inhibits Cyclin-CDK complexes Furthermore, Cyclin A2 plays a decisive role in regulation of $S$ phase and its deficiency will make cells accumulation in G0/G1 and decreases entry into $S$ phase, thereby induce proliferation arrest and apoptosis [34, 35].

In the current study, P21 was expressed mainly in the cytoplasm with few cases nucleo-cytoplasmic. This is consistent with other studies which reported cytoplasmic expression of P21 in hepatocellular carcinoma and BC

Table 5 Correlation between ROC-1 H score and both CAIX and P21 H-scores in malignant cases

\begin{tabular}{lll}
\hline Markers & \multicolumn{2}{l}{ ROC 1 H-score } \\
\cline { 2 - 3 } & $r$ & $P$ value \\
\hline CAIX H-score & -0.337 & $0.02^{*}$ \\
P21 H-score & -0.303 & $0.01^{*}$ \\
\hline
\end{tabular}

$r$ Spearman's rho, * significant respectively [33, 35]. Receptor tyrosine kinases and downstream components such as the Akt/PKB serine/ threonine kinase mediated P21 phosphorylation are essential for P21 localization in the cytoplasm. Inhibition of Akt retained P21 in the nucleus, resulting in less P21 complex formation with CDK2. However, Akt1dependent cytoplasmic localization of P21 occurs in a variety of cancers where it promotes tumorigenesis by inhibiting proteins essential for apoptosis [36].

Association of cytoplasmic P21with poor pathologic features (as muscle invasion, advanced pathological stage, presence of necrosis and increased mitosis) are in agreement with Wei et al. [30]. cytoplasmic P21 functions as an oncogene, therefore promoting cancer cell proliferation and progression through the cell cycle, so correlates positively with aggressive tumors and poor prognosis, whereas nuclear P21 was reported be involved in the prodifferentiating and senescence-promoting effects [37, 38].

In the present study; CAIX was expressed in only 4 out of 15 cases of normal urothelium while significantly expressed in malignant cases, compatible with other studies [39, 40]. This might be justified by the basic function of CAIX to help produce and maintain an intracellular $\mathrm{pH}(\mathrm{pHi})$ favorable for tumor cell growth and survival, while at the same time participating in the generation of an increasingly acidic extracellular space, facilitating tumor cell invasiveness [41].

In our study CAIX showed cytoplasmic and nuclear pattern of expression matched with many other studies [42-44]. It might be explained as; alternative splicing of the CAIX transcript, besides the predominant, fulllength CAIX mRNA, an alternatively spliced variant has been detected and is constitutively expressed at very low levels and codes for a truncated, cytoplasmic/secreted form of CAIX without enzymatic activity. This is very important for studies related to hypoxia-related expression of CAIX, where the presence of the alternatively spliced variant is hypoxia-independent and can provide a false-positive signal [45].

Association of CAIX overexpression with poor pathologic features as high grade UC $(P=0.01)$ and desmoplastic stroma $(P=0.024)$, were reported by others $[13$, 46], providing further evidence of CAIX as an aggressive marker in bladder cancer and a promising targeted therapy by its inhibition. 
Table 6 Univariate survival analysis for studied bladder carcinoma cases

\begin{tabular}{|c|c|c|c|c|}
\hline \multirow[t]{2}{*}{ Variable } & \multicolumn{4}{|c|}{ Overall survival (months) } \\
\hline & Mean survival time & SE & Log rank & $P$-value \\
\hline \multicolumn{5}{|l|}{ Gender } \\
\hline Male & 42.417 & 2.323 & 0.009 & 0.926 \\
\hline Female & 45.429 & 4.508 & & \\
\hline \multicolumn{5}{|l|}{ Age (years) } \\
\hline$\leq 60$ & 43.120 & 2.954 & 0.024 & 0.877 \\
\hline$>60$ & 42.209 & 2.979 & & \\
\hline \multicolumn{5}{|l|}{ Size of mass } \\
\hline Absent & 44.258 & 3.551 & 0.0 & 0.982 \\
\hline Present & 42.210 & 2.472 & & \\
\hline \multicolumn{5}{|l|}{ Diagnosis } \\
\hline TCC & 42.986 & 2.139 & 0.021 & 0.886 \\
\hline Squamous ca & 43.800 & 8.941 & & \\
\hline \multicolumn{5}{|l|}{ Grade } \\
\hline Poorly diff & 30.0 & 0.0 & 1.726 & 0.422 \\
\hline Moderate differ. & 47.250 & 10.872 & & \\
\hline High & 42.986 & 2.139 & & \\
\hline \multicolumn{5}{|l|}{ Bilharsiasis } \\
\hline Absent & 44.632 & 2.654 & 2.271 & 0.132 \\
\hline Present & 39.438 & 3.244 & & \\
\hline \multicolumn{5}{|l|}{ Necrosis } \\
\hline Absent & 43.615 & 2.475 & 0.047 & 0.829 \\
\hline Present & 40.857 & 3.787 & & \\
\hline \multicolumn{5}{|l|}{ LVI } \\
\hline Absent & 42.828 & 2.354 & 0.066 & 0.798 \\
\hline Present & 42.778 & 4.558 & & \\
\hline \multicolumn{5}{|l|}{ PNI } \\
\hline Absent & 43.537 & 2.203 & 1.211 & 0.271 \\
\hline Present & 37.833 & 6.263 & & \\
\hline \multicolumn{5}{|l|}{ Stroma } \\
\hline Inflammatory & 41.769 & 3.530 & 0.232 & 0.630 \\
\hline Desmoplastic & 43.252 & 2.559 & & \\
\hline \multicolumn{5}{|l|}{ Tumor stage } \\
\hline $\mathrm{T} 1$ & 44.258 & 3.551 & 1.922 & 0.589 \\
\hline $\mathrm{T} 2$ & 43.129 & 3.213 & & \\
\hline T3 & 39.054 & 3.823 & & \\
\hline T4 & 52.333 & 11.681 & & \\
\hline \multicolumn{5}{|l|}{ Ms invaion } \\
\hline Absent & 44.258 & 3.551 & 0.0 & 0.982 \\
\hline Present & 42.210 & 2.472 & & \\
\hline \multicolumn{5}{|l|}{ Node } \\
\hline Absent & 41.848 & 2.322 & 0.988 & 0.320 \\
\hline Present & 44.322 & 4.061 & & \\
\hline
\end{tabular}

Table 6 Univariate survival analysis for studied bladder carcinoma cases (Continued)

\begin{tabular}{|c|c|c|c|c|}
\hline \multirow[t]{2}{*}{ Variable } & \multicolumn{4}{|c|}{ Overall survival (months) } \\
\hline & Mean survival time & SE & Log rank & $P$-value \\
\hline \multicolumn{5}{|c|}{ Reactivity (ROC-1 Immunohistochemistry) } \\
\hline Negative & 59.0 & 0.0 & 1.454 & 0.228 \\
\hline Positive & 42.100 & 2.095 & & \\
\hline \multicolumn{5}{|c|}{ Pattern (ROC-1 Immunohistochemistry) } \\
\hline Negative & 59.0 & 0.0 & 2.415 & 0.299 \\
\hline Cytoplasmic & 40.134 & 3.038 & & \\
\hline Nuclear/cytopl & 42.940 & 2.723 & & \\
\hline \multicolumn{5}{|c|}{ H score (ROC-1 Immunohistochemistry) } \\
\hline Low median $(<90)$ & 43.904 & 2.904 & 0.044 & 0.834 \\
\hline High median (>90) & 41.947 & 2.987 & & \\
\hline \multicolumn{5}{|c|}{ IRS (ROC-1 Immunohistochemistry) } \\
\hline Low & 43.519 & 2.454 & 1.323 & 0.250 \\
\hline High & 40.700 & 3.950 & & \\
\hline \multicolumn{5}{|c|}{ Reactivity (CAIX Immunohistochemstry } \\
\hline Negative & 45.948 & 3.149 & 1.077 & 0.299 \\
\hline Positive & 40.856 & 2.703 & & \\
\hline \multicolumn{5}{|c|}{ Pattern (CAIX Immunohistochemstry } \\
\hline Negative & 45.948 & 3.149 & 1.077 & 0.299 \\
\hline Cytoplasmic & 40.856 & 2.703 & & \\
\hline \multicolumn{5}{|c|}{ H score (CAIX Immunohistochemstry } \\
\hline Low median $(<90)$ & 43.342 & 3.628 & 3.498 & 0.061 \\
\hline High median (>90) & 36.500 & 3.591 & & \\
\hline
\end{tabular}

No comparison analysis was performed for urothelial carcinoma and squamous cell carcinoma grades because the factor variable had only one value

Cl Confidence interval

Desmoplastic stromal reaction is a strong risk factor associated with metastasis. Hypoxia plays a role by promoting neo-angiogenesis via growth factors secreted by tumor cells and may lead to remodeling of tumor stroma and cause hypoxia inducible metastasis [47]. It is also associated with tumor necrosis regulating secretion of many factors involved in stroma formation as fibronectin, collagens, and metalloproteases [48]. Others propose that hypoxia could induce Mesenchymal - Epithelial transition, moreover, changes in intracellular and extracellular $\mathrm{pH}$ could be responsible for this kind of stromal reaction [46, 49, 50]. Hypoxic markers enhance glycolytic metabolism and lead to the generation of excess lactate, in this context, acidic $\mathrm{pH}$ is known to contribute to tumor cell invasiveness and could be an important contributing factor for the poor prognosis [50].

In this study, all the female cases showed significant expression of CAIX $(P=0.02)$. Many women ignore the most basic symptom (blood in the urine) which they may associate with menstruation or menopause. As a 
result, a bladder cancer diagnosis can be overlooked for a year or more [51]. Our results are supported by other studies [52].

Tumor necrosis is believed to represent the endpoint of severe, chronic hypoxia distal to functional blood vessels. CAIX expression related to necrosis and its predominance at the periphery of necrotic tumor tissue, indicates that CAIX positive tumor cells are more resistant to hypoxia and possess a growth advantage and determine its role in the protection of tumor cells from hypoxia and acidosis [43, 53]. Many studies reported a significant association between CAIX expression and presence of necrosis in different tumor types $[46,54,55]$.

In the current study, although $70 \%$ of UC that displayed necrosis $(14 / 20)$ expressed CAIX, yet there was no significant association. The reasons for the discrepancies with other studies are unknown; it might be related to the small sample size included in the current study.

However, evaluation of CAIX in the peri-necrotic areas and away from the necrotic areas revealed that all cases that expressed CAIX in the peri-necrotic areas were negative in the areas away from necrosis $(P=0.014)$, so the expression is increased around necrosis. This result hypothesizes that the necrosis may represent regions where CAIX expression has maintained a high level of proliferation through the maintenance of a more uniformly alkaline intracellular $\mathrm{pH}$. This would increase metabolic demand and deplete substrates in the hypoxic milieu. Also, necrosis induces infiltration of macrophages which may contribute to an aggressive tumor phenotype and necrosis is associated with poor prognosis in many cancer types. So the wellrecognized observation of CAIX staining around necrotic areas may reflect a role in necrosis [54].

In our study, there was a significant association between CAIX expression and presence of bilharziasis $(P=0.046)$. This might be explained as; chronic inflammation induced by bilharzial infection, had been identified as a key inducer of epithelial mesenchymal transition (EMT) during cancer progression through upregulation of mesenchymal markers and thus promoting metastasis $[56,57]$. CAIX considered an EMT inducer [58] and a mesenchymal marker [59] as it played a specific role in EMT by causing extracellular acidification which closely associated with breakdown of the extracellular matrix (ECM), growth factors and protease activation. Also, expression of CAIX leads to its co-localization with $\beta$-catenin and disruption of cell-cell adhesion. Its role in EMT keeping with its ability to sense hypoxia as several components of the tumor microenvironment have been described to elicit or enhance the EMT of cancer cells, including intratumoral hypoxia [60].
Regarding the relation between the studied markers (ROC-1, CAIX and p21) with each other, a significant inverse relationship between $\mathrm{H}$ - score of ROC-1 and both CAIX and P21 in BC cases was noted. This finding might be promising in using these biomarkers as a targeted therapy in treating $\mathrm{BC}$ in Egyptian patients by causing Knockdown of ROC-1 by siRNA silencing which induce CRL inactivation that cause accumulation of some special CRL substrates such as P21 causing arrested bladder cancer cells at G2 phase [58]. So, P21upregulation targeting different regions of its promoters are an ideal method of gain of function manipulation to suppress BC cell growth [34]. Also, Upon ROC-1 siRNA silencing, it disassembles CRL/SCF complexes and thus inhibits CRL/SCF activity. As the result, DNA replication licensing proteins CDT1 and ORC1, two well-known CRL/SCF substrates, accumulate to trigger DNA damage response, leading to $\mathrm{G} 2-\mathrm{M}$ cell cycle arrest, senescence and/or apoptosis in cancer cells [59].

On the other hand inhibition of CAIX could be induced by upregulating ROC-1; this idea can be used as base for treating $\mathrm{BC}$ by causing CAIX inhibition because ROC-1 mediate un stabilization and degradation of hypoxic markers by ubiquitation of VHL as it is a component of VHL/Cullin 2/ Elongin BC/ ROC-1 complex [27]. There was also a significant direct relationship between CAIX and P21 $\mathrm{H}$-score in the current study, suggesting an association in carcinogenesis and aggressiveness of BC.

\section{Conclusion}

ROC-1, CAIX and P21 may serve as markers of aggressiveness, poor prognosis and prediction of tumor aggressiveness in bladder carcinoma in Egyptian patients. ROC-1 could be a promising candidate biomarkers that might serve as targeted therapy in hypoxic microenvironment of $\mathrm{BC}$; for ROC-1 knockdown induces up regulation of P21, leading to apoptosis of BC cells, while up regulating ROC-1 leads to inhibition of CAIX. As for CAIX it may serve as potentially important disease biomarker for the identification of high risk and poor prognostic patients who may benefit from targeted therapy.

\begin{abstract}
Abbreviations
ROC-1: Regulator of Cullins-1; BC: Bladder cancer; CRL: Cullin-RING ligases; CKIs: Cyclin dependent kinase inhibitors; CDKs: Cyclin- Dependent Kinases; IHC: Immunohistochemical; RBX1: RING box protein-1; CIP/KIP: CDK Interacting Protein/Kinase Inhibitor Protein; AJCC-UICC: American Joint Committee on Cancer-Union International Center Cancer staging system; NMIBC: Non-muscle- invasive bladder cancer; MIBC: Muscle invasive bladder cancer; UC: Urothelial carcinoma; TGF- $\beta$-: Transforming growth factor beta; EMT: Epithelial mesenchymal transition
\end{abstract}

Acknowledgements

Not applicable.

\section{Authors' contributions}

AL-Sharaky DR- participated in histopathological assesement of the stained slides, interpretation of the results, analysis and a contributor in writing the 
manuscript. Kandil MA- participated in interpretation of the results, analysis and writing the discussion. Aiad HA- participated in interpretation of the results, analysis and writing the discussion. ELhosary E- participated in histopathological assesement of the stained slides, interpretation of the results, analysis and writing the manuscript. Alagizy HA- provided the survival data of the studied cases. Alshenawy MA- provided the survival data of the studied cases. El-Rebey HS- participated in histopathological assesement of the stained slides, interpretation of the results, analysis and writing the manuscript. All authors read and approved the final manuscript.

\section{Funding}

No fund was contributed to the current study.

\section{Availability of data and materials}

The data that support the findings of this study are available from [third party name] but restrictions apply to the availability of these data, which were used under license for the current study, and so are not publicly available. Data are however available from the authors upon reasonable request and with permission of [third party name].

\section{Ethics approval and consent to participate}

The ethics committee in the faculty of medicine Menoufia University approved the purpose of this retrospective study and the use of archival paraffin blocks to evaluate the expression of the studied primary antibodies.

\section{Consent for publication}

Not applicable.

\section{Competing interests}

The authors declare that they have no competing interests.

\section{Author details}

'Department of Pathology, Faculty of Medicine, Menoufia University, Shebin El-Kom, Menoufia Governorate 35211, Egypt. ${ }^{2}$ General hospital, Shebin El-Kom, Menoufia Governorate, Egypt. ${ }^{3} \mathrm{Clinical}$ oncology \& Nuclear medicine Department, Faculty of Medicine, Menoufia University, Shebin El-Kom, Egypt.

\section{Received: 30 October 2019 Accepted: 19 March 2020}

\section{Published online: 07 April 2020}

\section{References}

1. Ibrahim AS, Khaled HM, Mikhail NNH, Baraka H, Kamel H. Cancer incidence in Egypt: results of the national population-based cancer registry program. J Cancer Epidemiol. 2014. https://doi.org/10.1155/2014/437971.

2. Elshikh EA, Anan I, Ebaid AA, Gamal DAA, Hamed MM, Mouein EA. The National Cancer Registry in Egypt a retrospective cross sectional epidemiological study. In: ISPOR 18th Annual European Congress; 2015. https://doi.org/10.1016/j.jval.2015.09.1059.

3. Petroski MD, Deshaies RJ. Function and regulation of cullin-RING ubiquitin ligases. Nat Rev Mol Cell Biol. 2005;6:9-20.

4. Jia L, Soengas MS, Sun Y. ROCI/RBX1 E3 ubiquitin ligase silencing suppresses tumor cell growth via sequential induction of G2-M arrest, apoptosis, and senescence. Cancer Res. 2009;69:4974-82.

5. Gabrielli R, Rosati MS, Siani A, Irace L. management of symptomatic venous aneurysm. ScientificWorldJournal. 2012;2012:386478.

6. Wang W, Qiu JX, Liu Z, Guo Y, Zeng Y, Fan J, et al. Overexpression of RING box protein-1 (RBX1) associated with poor prognosis of non-muscle-invasive bladder transitional cell carcinoma. J Surg Oncol. 2013;107:758-61.

7. Bartek J, Lukas J. DNA damage checkpoints: from initiation to recovery or adaptation. Curr Opin Cell Biol. 2007;19:238-45.

8. Supuran CT. Carbonic anhydrase inhibitor. Bioorg Med Chem Lett. 2010;20: 3467-74.

9. Moch $\mathrm{H}$, Humphrey PA, Ulbright TM, Reuter $\mathrm{V}$, editors. Tumors in urinary tract. WHO classification of tumours of the urinary system and male genital organs. Lyon: International Agency for Research on Cancer; 2016. p. 78-130.

10. Chauhan R, Verma N, Sharma SP, Bhargava R, Singh P. Role of apoptotic index, mitotic index and MIB-1 antibody expression as biomarkers in preneoplastic and neoplastic lesions of uterine cervix. Int J Res Med Sci. 2016;4(6):2093-100.
11. Michail O, Moris D, Theocharis S, Griniatsos J. Cullin-1 and -2 protein expression in colorectal cancer: correlation with clinicopathological variables. In Vivo. 2018;32(2):391-6. https://doi.org/10.21873/invivo.11251.

12. Shariat SF, Kim J, Rapitidis G, Ayala GE, Lerner SP. Association of p53 and p21 expression with clinical outcome in patients with carcinoma in situ of the urinary bladder. Urology. 2003;61:1140-5.

13. Trastour C, Benizri E, Ettore F, Ramaioli A, Chamorey E, Pouyssegur J, et al. HIF-1alpha and CA IX staining in invasive breast carcinomas: prognosis and treatment outcome. Int J Cancer. 2007;120:1451-8.

14. Dawson B, Trapp R, editors. Basic and clinical biostatistics: large medical books. Oxford: Boston; 2001. p. 270-5.

15. Migita K, Takayama T, Matsumoto S, Wakatsuki K, Tanaka T, Ito M, et al. Prognostic impact of RING box protein-1 (RBX1) expression in gastric cancer. Gastric Cancer. 2014;17:601-9.

16. Yang $Y$, Sun M, Wang L, Jiao B. HIFs, angiogenesis, and cancer. J Cell Biochem. 2013;114:967-74.

17. Randle SJ, Laman H. F-box protein interactions with the hallmark pathways in cancer. Semin Cancer Biol. 2016;36:3-17.

18. Wang W, Chen H, Liu Z, Qu P, Lan J, Chen H, et al. Regulator of cullins-1 expression knockdown suppresses the malignant progression of muscleinvasive transitional cell carcinoma by regulating mTOR/DEPTOR pathway. Br J Cancer. 2016;114:305-13.

19. Gong X, Litchfield LM, Webster Y, Chio LC, Wong SS, Stewart TR, et al. Genomic aberrations that activate D-type cyclins are associated with enhanced sensitivity to the CDK4 and CDK6 inhibitor Abemaciclib. Cancer Cell. 2017;32(6):761-76.

20. Gherardi E, Birchmeier W, Birchmeier C, VandeWoude G. Targeting MET in cancer: rationale and progress. Nat Rev Cancer. 2012;12:89-103.

21. Betz C, Hall MN. Where is mTOR and what is it doing there? I Cell Biol. 2013;203:563-74.

22. Gordon EM, Laumann TO, Adeyemo B, Huckins JF, Kelley WM, Petersen SE. Generation and evaluation of a cortical area Parcellation from resting-state correlations. Cereb Cortex. 2016;26:288-303.

23. Lamouille $\mathrm{S}, \mathrm{Xu}$ J, Derynck R. Molecular mechanisms of epithelialmesenchymal transition. Nat Rev Mol Cell Biol. 2014;15:178-96.

24. Ueno H, Shinto E, Kajiwara Y, Fukazawa S, Shimazaki E, Yamamoto J. Prognostic impact of histological categorisation of epithelial-mesenchymal transition in colorectal cancer. Br J Cancer. 2014;111:2082-90.

25. Lundgren K, Holm C, Landberg G. Hypoxia and breast cancer: prognostic and therapeutic implications. Cell Mol Life Sci. 2007;64:3233-47.

26. Zhou W, Dosey TL, Biechele T, Moon RT, Horwitz MS, Ruohola-Baker H. Assessment of hypoxia inducible factor levels in cancer cell lines upon hypoxic induction using a novel reporter construct. PLoS One. 2011;6: e27460.

27. Cardote TAF, Gadd MS, Ciulli A. Crystal structure of the Cul2-Rbx1-EloBC-VHL ubiquitin ligase complex. Structure. 2017;25:901-11.

28. Shariat SF, Alexandre RZ, Raheela A, Arthur IS, Yair L. Cooperative effect of cell-cycle regulators expression on bladder cancer development and biologic aggressiveness. Mod Pathol. 2007;20:445-59.

29. Liu X, Yu H, Cai H, Wang Y. Expression of CD24, p21, p53, and c-myc in alpha-fetoprotein-producing gastric cancer: correlation with clinicopathologic characteristics and survival. J Surg Oncol. 2014;109:859-64.

30. Huang WJ, Jeng YM, Lai HS, Fong IU, Sheu FY, Lai PL, Yuan RH. Expression of Hypoxic Marker Carbonic Anhydrase IX Predicts Poor Prognosis in Resectable Hepatocellular Carcinoma. PLoS One. 2015;10(3):e0119181.

31. Han J, Wang F, Yuan SQ, Guo Y, Zeng ZL, Li LR, et al. Reduced expression of p21-activated protein kinase 1 correlates with poor histological differentiation in pancreatic cancer. BMC Cancer. 2014;14:650.

32. Xie D, Lan L, Huang K, Chen L, Xu C, Wang R, et al. Association of p53/p21 expression and cigarette smoking with tumor progression and poor prognosis in non-small cell lung cancer patients. Oncol Rep. 2014;32: 2517-26.

33. Tang $\mathrm{K}$, Wang $\mathrm{C}$, Chen Z, Xu H, Ye Z. Clinicopathologic and prognostic significance of p21 (Cip1/Waf1) expression in bladder cancer. Int J Clin Exp Pathol. 2015;8(5):4999-5007.

34. Wang C, Ge Q, Chen Z, et al. New double stranded RNA suppresses bladder Cancer development by Upregulating p21Waf1/CIP1 expression. Biomed Res Int. 2015. https://doi.org/10.1155/304753.

35. Dai L, Liu Y, Liu J, Wen X, Xu Z, Wang Z, et al. A novel CyclinE/CyclinA-CDK inhibitor targets p27Kip1 degradation, cell cycle progression and cell survival: implications in cancer therapy. Cancer Lett. 2013;333:103-12. 
36. De Renty C, De Pamphilis ML, Ullah Z. Cytoplasmic Localization of p21 Protects Trophoblast Giant Cells from DNA Damage Induced Apoptosis. PLoS One. 2014;9:e97434.

37. Cheng $X$, Xia W, Yang JY, Hsu JL, Chou CK, Sun HL, et al. Activation of p21(CIP1/WAF1) in mammary epithelium accelerates mammary tumorigenesis and promotes lung metastasis. Biochem Biophys Res Commun. 2010:403:103-7.

38. Diaz-Moralli S, Tarrado-Castellarnau M, Miranda A, Cascante M. Targeting cell cycle regulation in cancer therapy. Pharmacol Ther. 2013;138:255-71.

39. Klatte T, Seligson DB, Rao JY, Yu H, de Martino M, Kawaoka K, et al. Carbonic anhydrase IX in bladder cancer: a diagnostic, prognostic, and therapeutic molecular marker. Cancer. 2009;115:1448-58.

40. Wykoff CC, Beasley NJ, Watson PH, Turner KJ, Pastorek J, Sibtain A, Wilson GD, Turley H, Talks KL, Maxwell PH, Pugh CW, Ratcliffe PJ, Harris AL. Hypoxia-inducible expression of tumor-associated carbonic anhydrases. Cancer Res. 2000;15(60):7075-83.

41. PC MD, Winum JY, Supuran CT, Dedhar S. Recent Developments in Targeting Carbonic Anhydrase IX for Cancer Therapeutics. Oncotarget. 2012;3:84-97.

42. Hunter BA, Eustace A, IrlamJ J, Valentine HR. DenleyH, Oguejiofork K, et al. expression of hypoxia-inducible factor-1a predicts benefit from hypoxia modification in invasive bladder cancer. Br J Cancer. 2014;111:437-43.

43. Finkelmeier F, Canli O, Peiffer K-H, Walter D, Tal A, Koch C, et al. Circulating hypoxia marker carbonic anhydrase IX (CA9) in patients with hepatocellular carcinoma and patients with cirrhosis. PLoS One. 2018;13:e0200855.

44. Ambrosio MR, Di Serio C, Danza G, Rocca BJ, Ginori A, Prudovsky I, et al. Carbonic anhydrase IX is a marker of hypoxia and correlates with higher Gleason scores and ISUP grading in prostate cancer. Diagn Pathol. 2016;11:45.

45. Barathova M, Takacova M, Holotnakova T, Gibadulinova A, Ohradanova A, Zatovicova M, et al. Alternative splicing variant of the hypoxia marker carbonic anhydrase IX expressed independently of hypoxia and tumour phenotype. Br J Cancer. 2008;98:129-36.

46. Samaka RM, Abd El-Waheda MM, Al Sharaky DR, Aleskandarany MA, Shehata MA, Hegazy SE. Carbonic anhydrase IX expression and localization in breast carcinoma. Menoufia Med J. 2015;28:693-701.

47. Koperek O, Bergner O, Pichlhöfer B, Oberndorfer F, Hainfellner JA, Kaserer K, et al. Expression of hypoxia-associated proteins in sporadic medullary thyroid cancer is associated with desmoplasticstroma reaction and lymph node metastasis and may indicate somatic mutations in the VHL gene. J Pathol. 2011;225:63-72

48. Elvidge GP, Glemyl L, Appelhoff RJ. Concordant regulation of gene expression by hypoxia and 2-oxoglutrate dependantdioxygenase inhibition: the role of HIF-1, HIF-2, and other pathways. J Biol Chem. 2006;281:15215-26.

49. Voss MJ, Möller MF, Powe DG, et al. Luminal and basal-like breast cancer cells show increased migration induced by hypoxia, mediated by an autocrine mechanism. BMC Cancer. 2011;11:158. https://doi.org/10.1186/ 1471-2407-11-158.

50. Knudsen ES, Balaji U, Freinkman E, McCue P, Witkiewicz AK. Unique metabolic features of pancreatic cancer stroma: relevance to the tumor compartment, prognosis, and invasive potential. Oncotarget. 2016;7:78396-411.

51. Manish IP, Albert B, David G, Rajkumar C, David PS. Poor survival of females with bladder cancer is limited to those aged 70 years or over: a populationwide linkage study, New South Wales, Australia. Cancer Med. 2015;4:1145-52.

52. Liao SY, Darcy KM, Randall LM, Tian C, Monk BJ, Burger RA, et al. Prognostic relevance of carbonic anhydrase-IX in high-risk, early-stage cervical cancer: a gynecologic oncology group study. Gynecol Oncol. 2010;116:452-8.

53. Csaderova L, Debreova M, Radvak P, Stano M, Vrestiakova M, Kopacek J, Pastorekova S, Svastova E. The effect of carbonic anhydrase IX on focal contacts during cell spreading and migration. Front Physiol. 2013. https:// doi.org/10.3389/fphys.00271.

54. McIntyre AL, Patiar S, Wigfield S, Li JL, Ledaki I, Turley H, et al. Carbonic anhydrase IX promotes tumor growth and necrosis in vivo and inhibition enhances anti-VEGF therapy. Clin Cancer Res. 2012;18:3100-11.

55. Eustace A, Mani N, Span PN, Irlam JJ, Taylor J, Betts NJ, et al. A 26-gene hypoxia signature predicts benefit from hypoxia-modifying therapy in laryngeal cancer but not bladder cancer. Clin Cancer Res. 2013;19:4879-88.

56. Grivennikov SI, Greten FR, Karin M. Immunity, inflammation, and cancer. Cell. 2010;140:883-99.

57. Cohen EN, Gao H, Anfossi S, Mego M, Reddy NG, Debeb B, et al. Inflammation mediated metastasis: immune induced epithelial-to- mesenchymal transition in inflammatory breast cancer cells. PLoS One. 2015;10(7):e0132710.

58. Fiaschi T, Giannoni E, Taddei ML, Cirri P, Marini A, Pintus G, et al. Carbonic anhydrase IX from cancer-associated fibroblasts drives epithelialmesenchymal transition in prostate carcinoma cells. Cell Cycle. 2013;12: $1791-801$.

59. Jia L, Bickel JS, Wu J, Morgan MA, Li H, Yang J, Yu X, Chan RC, Sun Y. RBX1 (RING box protein 1) E3 ubiquitin ligase is required for genomic integrity by modulating DNA replication licensing proteins. J Biol Chem. 2011;286:3379-86.

60. Giannoni E, Bianchini F, Masieri L, Serni S, Torre E, Calorini L, et al. Reciprocal activation of prostate cancer cells and cancer-associated fibroblasts stimulates epithelial-mesenchymal transition and cancer stemness. Cancer Res. 2010;70:6945-56.

\section{Publisher's Note}

Springer Nature remains neutral with regard to jurisdictional claims in published maps and institutional affiliations.
Ready to submit your research? Choose BMC and benefit from:

- fast, convenient online submission

- thorough peer review by experienced researchers in your field

- rapid publication on acceptance

- support for research data, including large and complex data types

- gold Open Access which fosters wider collaboration and increased citations

- maximum visibility for your research: over $100 \mathrm{M}$ website views per year

At BMC, research is always in progress.

Learn more biomedcentral.com/submissions 